\title{
MENCIPTAKAN GREEN BRAND PERSONALITY BAGI MEREK RAMAH LINGKUNGAN
}

\author{
Gede Suparna ${ }^{(1)}$ \\ Ni Wayan Ekawati ${ }^{(2)}$ \\ I Gusti Agung Ketut Gede Suasana ${ }^{(3)}$ \\ Anak Agung Ayu Sriathi ${ }^{(4)}$ \\ (1),(2),(3),(4)Fakultas Ekonomi dan Bisnis Universitas Udayana, Bali, Indonesia \\ email:niwayanekawati@gmail.com
}

\begin{abstract}
ABSTRAK
Tujuan penelitian ini adalah menjelaskan pengaruh green brand terhadap green brand personality, pengaruh green brand terhadap green brand image, pengaruh green brand image terhadap green brand personality, perangreen brand imagesebagai mediasi pengaruh green brand terhadap green brand personality. Penelitian dilakukan pada masyarakat di Bali,menggunakan sampel individu sebagai unit analisis sebanyak 110 responden. Teknik analisis yang digunakan adalah analisis kuantitatif berdasarkan analisis multivariate menggunakan model persamaananalisis struktural atau SEM (structural equation modeling) berbasis AMOS 7.0. Hasil analisis menemukan terdapat pengaruh green brand terhadap green brand personality dan green brandimage, terdapat pengaruh green brand image terhadap green brand personality, dan green brand image tidak berperan sebagai variabel mediasi.
\end{abstract}

Kata kunci: merek hijau, citra merek hijau, kepribadian merek hijau

\begin{abstract}
The purpose of this research is to explain the influence of green brand to green brand personality, the influence of green brand toward green brand image, the influence of green brand image on green brand personality, the role of green brand image as mediating the influence of green brand on green brand personality. The study was conducted on the community in Bali, using individual samples as an analysis unit of 110 respondents. The analysis technique used is quantitative analysis based on multivariate analysis using structural equation modeling model based on AMOS 7.0. The results of the analysis found that there is influence of green brand on green brand personality and green brand image, there is influence of green brand image to green brand personality, and green brand image does not act as mediation variable.

Keywords: green brand, green brand image, green brand personality.
\end{abstract}

\section{PENDAHULUAN}

Isu pencemaran lingkungan sudah menjadi masalah yang cukup penting belakangan ini. Pencemaran lingkungan ini disebabkan oleh banyak hal salah satunya adalah adanya keterlibatan peran wirausaha dalam menciptakan pencemaran lingkungan yang ada (Scapher, 2010). Pencemaran lingkungan alam apabila dibiarkan berlarut-larut sangat berpengaruh pada keselamatan biota alam yang ada. Semua itu akan berdampak pada kelangsungan kehidupan mahluk hidup (Schaltegger, 2002). Terdapat sebuah artikel yang diungkapkan oleh national geographic pada 13 Februari 2015 menyebutkan Indonesia termasuk dalam 10 besar negara yang berkontribusi dalam menciptakan pencemaran lingkungan laut yaitu berupa sampah plastik (news.nationalgeographic.com). Pernyataan tersebut sudah pasti berpengaruh pada nama baik negara Indonesia sebagai negara maritim yang memiliki kawasan laut sangat luas. Untuk itu perlu dilaksanakan berbagai upaya untuk menjaga terjadinya pencemaran lingkungan laut. Salah satunya adalah dengan melibatkan konsumen, masyarakat, pemerintah maupun wirausaha.

Wirausaha sebagai penghasil produk dan jasa diharapkan mampu berkontribusi dalam upaya menjaga lingkungan alam, yaitu berupaya untuk menghasilkan produk dan jasa yang ramah lingkungan (Ekawati et al., 2017). Atau diistilahkan juga dengan produk hijau (green product). Produk alami sering diidentikkan dengan produk ramah lingkungan. Saat ini sudah cukup banyak beredar di pasar yang termasuk katagorikan produk alami (green product). Seperti produk makanan, obatobatan, produk kesehatan, perlengkapan rumah tangga, dan kerajinan serta lainnya. Terutama produk kesehatan berbahan herbal sudah mulai adanya peningkatan permintaan. Produk kesehatan berbahan herbal dapat berupa makanan, minuman maupun suplemen kesehatan. 
Beberapa produk ekstrak herbal mempunyai pasar global dengan nilai yang besar. Ginko Biloba, Ginseng, Garlic dan Echinacae adalah ekstrak yang memiliki pasar tergolong terbesar di dunia (Warta Ekspor, 2014). Amerika Serikat menunjukkan tingkat penjualan dan penggunaan obat herbal berupa dietary supplement juga meningkat cukup signifikan. Seperti contoh jamu sebagai salah satu obat herbal tradisional Indonesia merupakan warisan budaya bangsa perlu terus dikembangkan dan dilestarikan dengan fokus utama pada aspek mutu dan keamanannya (safety). Demikian pula peningkatan permintaaan terjadi pada masyarakat di Bali. Masyarakat sebagai konsumen juga dituntut kejeliannya dalam memenuhi kebutuhan hidup yang juga ikut serta menjaga lingkungan alam (Budak et al., 2005).

Menumbuhkan upaya menjaga lingkungan dapat terbentuk dari produk-produk ramah lingkungan dengan berbagai merek yang ditawarkan produsen dan mampu meningkatkan kesan yang baik bagi merek produk ramah lingkungan (green brand). Brand merupakan nama, istilah, tanda, simbol, rancangan, atau kombinasi dari semuanya yang dimaksudkan untuk mengenali produk atau jasa dari seseorang atau penjual dan untuk membedakannya dari produk pesaing. Brand mampu mengidentifikasi pembuat atau penjual dari suatu produk. Brand juga merupakan janji penjual untuk menyampaikan kesimpulan sifat, manfaat, dan jasa spesifik secara konsisten kepada pembeli (Tan et al., 2012).

Green brand adalah sebagai salah satu alat komunikasi yang memberikan informasi tenteng merek dan manfaat unik produk khususnya mengurangi dampak lingkungan, dan menyajikan atribut produk ramah lingkungan (Huang dan Yang, 2014). Green brand adalah penciptaan merek yang berkomitmen terhadap upaya pelestarian lingkungan yang merupakan bagian dari strategi perusahaan memerlukan dukungan semua pihak (Hartman et al., 2005), sehingga membuat posisi merek menjadi kuat sebagai tujuan utama dari perusahaan dan pemasar, karena diharapkan mampu memberikan margin yang lebih besar, kesempatan yang lebih besar untuk memperpanjang dan memelihara posisi yang kuat terhadap pesaing (Delgado dan Munuera, 2005).

Kondisi tersebut mengharapkan keikutsertaan konsumen menjaga lingkungan yang dapat menciptakan suatu ketertarikan dan ikatan secara pribadi terhadap merek produk hijau. Kepribadian merek tersebut diistilahkan dengan green brand personality. Melalui Green brand personality memainkan peranan yang penting pada kondisi aktivitas pemasaran saat ini dengan tujuan melestarikan lingkungan (Chen dan Chang, 2016).

Ikatan secara pribadi yang dimiliki konsumen terhadap suatu merek ramah lingkungan akan cenderung lebih mengesankan dan lebih baik dibandingkan dengan merek yang tanpa memiliki kepribadian. Brand personality adalah seperangkat karakteristik manusia yang memiliki keterkaitan dengan merek. Ibaratnya sama seperti manusia dimana merek dapat memiliki berbagai kepribadian seperti menjadi profesional ataupun menjadi suatu kompetensi (Aaker, 2008).

Brand personality saat ini menjadi topik yang menarik dan penting dalam penelitian bidang pemasaran, dikarenakan sangat membantu untuk membedakan satu merek dengan merek lainnya. Selain itu juga brand personality mampu membangun aspek emosional, dan memperbesar makna personal (kepribadian) suatu merek. Brand personality melibatkan karakteristik yang terdapat pada kepribadian manusia atau konsumen dan karakteristik yang dimiliki suatu merek atau produk yang mampu memberikan sesuatu yang terdiferensiasi dan berpengaruh pada perilaku konsumen (Aaker, 1997). Brand Personality memegang peranan yang sangat penting dalam mempengaruhi sikap konsumen dan perilaku konsumen, hal itu diungkapkan oleh banyak literatur (Sirgy, 1982).Green brand personality pada merek produk ramah lingkungan akan sangat membantu dalam membentuk citra merek dengan karakteristik produk alami.Green brand personality yang baik akan muncul sebagai akibat merek yang bersangkutan mampu menciptakan pandangan atau anggapan (green brand image) yang baik pula.

Menciptakan sebuah green branding positif untuk merek-merek produk ramah lingkungan bukanlah merupakan hal yang mudah, terutama menciptakan green brand image untuk suatu merek produk baru seperti merek pada produk ramah lingkungan yang sudah mulai memasuki pasar. Penelitian perilaku konsumen menganggap bahwa brand image sebagai salah satu komponen yang sangat penting dalam kegiatan pemasaran (Hee, 2009). Brand image akan terbentuk dari pikiran pelanggan dengan banyak hal yang terkait dengan produk, yang tidak hanya dipengaruhi oleh beragam pesan, jumlah pesan dan pesan sering berubah-ubah.

Brand Image dibangun dalam pikiran masingmasing konsumen berdasarkan serangkaian persepsi 
yang muncul serta hal-hal yang ditanamkan perusahaan terhadap produk (Ismail dan Spinelli, 2012). Brand Image juga merupakan serangkaian citra atau persepsi yang ingin dibentuk perusahaan terhadap merek yang dipasarkan sehingga menjadi salah satu pembeda dengan pesaing-pesaingnya (Lee dan Kang, 2012). Berdasarkan itulah green brand image menjadi salah satu hal yang penting untuk diteliti, khususnya untuk produk ramah lingkungan. Terdapat temuan menarik oleh Alshura dan Zabad (2016) yang menyatakan green brand image tidak menjadi variabel penting karena tidak berpengaruh pada keberadaan green product dan keputusan pembelian konsumen.

Produk ramah lingkungan atau produk hijau saat ini sudah mulai masuk pasar konsumen, dan konsumen sudah banyak mulai beralih pada produk ramah lingkungan (Shobeiri, 2006). Dengan demikian, sangat dibutuhkan komitmen yang kuat untuk mampu menyediakan produk hijau yang berkualitas. Karakteristik yang terdapat pada sebuah produk hijau harus dapat menjadi nilai utama yang bisa ditawarkan kepada konsumen. Sebab manfaat dan nilai yang ditawarkan dapat memberikan citra secara pribadi pada konsumen (Paulray, 2008). Keberhasilan daripada green brand akan membentuk green brand image positif. Green brand image sangat diharapkan mampu membentuk green brand personality yang melekat pada konsumen. Green brand personality yang baik terbentuk dari kepuasan konsumen terhadap penggunaangreen brand dengan segala atributnya dan green brand image.

Berdasarkan pemaparan tersebut, penulis melihat bahwa green brand khususnya merek produk kesehatan yang dapat berupa makanan, minuman dan suplemenkesehatan diharapkan mampu membentuk green brand image dangreen brand personality. Green brand kesehatan yang akan diteliti lebih lanjut adalah tidak mengkhusus pada satu merek. Hal tersebut disebabkan karena hingga saat ini green brand yang sudah masuk pasar Bali, bagi masyarakat belum ada merek kesehatan dengan merek tertentu yang betul-betul diminati konsumen. Karena merek-merek tersebut baru memasuki masa perkenalan dimasyarakat dan kurangnya aktifitas promosi bagi green brand.

Penelusuran awal menunjukkan bahwa terdapat kecenderungan signifikan terhadap kebutuhan konsumen akan produk-produk alami (green product) khususnya makanan, minuman dan suplemen kesehatan dengan berbagai merek (green brand). Peningkatan kebutuhan akan produk alami dengan merek yang ditawarkan menandakan bahwa produk dan merek tersebut dapat diterima dengan baik. Green brand yang mendapatkan sambutan baik di masyarakat menandakan adanya gejala mampu menciptakan green brand image dan green brand personality pada konsumennya. Gejala tersebut memerlukan identifikasi lebih lanjut akan kebenarannya, sebagai langkah awal perusahaan untuk menentukan strategi selanjutnya. Sehingga menjadi variabel penting untuk diteliti lebih lanjut. Apakah gejala tersebut nantinya dapat menjadi peluang untuk mengembangkan strategi green brand makanan kesehatan.

Selain itu, dimotivasi adanya banyak himbauan untuk kembali ke alam, serta upaya mendukung Bali sebagai green province. Penelitian terkait dengan green product masih sangat sedikit, apalagi berkaitan dengan green brand. Termasuk belum adanya penelitian yang melibatkan variabel green brandpada produk kesehatan,pengaruhnya terhadap green brand imagedan green brand personality.

Berdasarkan latar belakang yang sudah diuraikan sebelumnya maka rumusan permasalahan penelitian sebagai berikut. a) Bagaimanakah pengaruh green brand terhadap green brand personality produk kesehatan di Bali?; b) Bagaimanakah pengaruh green brand terhadap green brand image produk kesehatan di Bali?, c) Bagaimanakah pengaruh green brand image terhadap green brand personality produk kesehatan di Bali?, d) Bagaimanakah peran greenbrand image sebagai mediasi pengaruh green brand terhadap greenbrand personality produk kesehatan di Bali?

Green product merupakan produk yang dirancang untuk meminimalkan dampak lingkungan selama siklus hidup produk tersebut, secara khusus penggunaan sumber daya yang tidak dapat diperbarui diminimalkan, bahan beracun dihindari dan penggunaan sumber daya yang dapat diperbarui sesuai dengan tingkat keperluan (Albino, 2009). Karakteristik green product yang sangat jelas biasanya produk tidak tahan lama, terbuat dari bahanbahan alami, dan menggunakan kemasan yang mudah didaur ulang.

Green product adalah produk yang memiliki manfaat positif bagi konsumen dan juga memiliki manfaat sosial yang dirasakan oleh konsumenyaitu ramah terhadap lingkungan alam sejak proses produksi hingga dikonsumsi (D'Souza et al., 2006).Kriteria green product menurut D'Souza et al. (2006) dalam penelitiannya menjelaskan bahwa presepsi produk dari sisi konsumen melihat bahwa 
green product atau produk ramah lingkungan sebagai produk yang tidak berbahaya terhadap hewan dan lingkungan alam. Kemasan produk mampu menyajikan elemen tertentu dan nampak adanya keterkaitan dengan kepedulian lingkungan. Komposisi dari bahan daur ulang dapat menunjukkan pemakaian bahan yang memiliki batas tertentu dan menunjukkan dengan tegas pemakaian secara keseluruhan dengan tingkat atau jumlah yang lebih rendah, serta meminimumkan timbulnya kerusakan terhadap lingkungan.

Produk ramah lingkungan merupakan suatu produk yang dirancang dan diproses dengan suatu cara untuk mengurangi efek-efek yang dapat mencemari lingkungan, baik dalam proses produksi, pendistribusian, dan ketika menkonsumsinya (Ekawati et al., 2016). Produk yang diperjualbelikan dimasyarakat senyatanya tidak ada jenis produk ramah lingkungan yang benar-benar murni sebagai produk ramah lingkungan yang diistilahkan dengan green product. Secara intensif pengelolaan untuk menghasilkan produk ramah lingkungan intinya adalah segala aktifitas diupayakan untuk mampu menjaga lingkungan alam seperti dalam hal penggunaan energi, sumber daya, dan emisi dalam proses pembuatan, distribusi, penggunaan, hingga dalam tahap pembuangan akhirnya. Artinya, katagori produk hijau (green product) sebenarnya adalah relatif dan merupakan deskripsi dari produk yang menimbulkan sedikit dampak terhadap lingkungan (Ottman, 1998).

Rath (2013) menyebutkan bahwa green product merupakan hasil produk-produk industri yang diproduksi menggunakan teknologi ramah lingkungan dan tidak menyebabkan bahaya terhadap lingkungan. Indikator green product yang digunakan sering merujuk pada pendapat Elkington et al. (1997), diantaranya (1) tingkat bahaya produk bagi kesehatan manusia, (2) kemasan yang ditimbulkan produk, (3) material bahan baku, dan (4) sertifikat ecolabel/sertifikat produk ramah lingkungan. Indikator-indikator tersebut juga dirujuk oleh peneliti lainnya seperti Octaviani (2013). Sehingga, dapat disimpulkan bahwa produk hijau merupakan suatu produk yang termasuk katagori ramah lingkungan atau tidak berbahaya terhadap lingkungan alam, baik saat proses produksinya maupun saat mengkonsumsinya.

Salah satu alternatif strategi pemasaran yang dapat diterapkan oleh perusahaan yang menawarkan produk ramah lingkungan adalah melalui green brand. Joachimsthaler dan Aaker dalam Hardvard (1999:5) menyatakan bahwa identitas dari suatu merek merupakan suatu konsep yang muncul dari perusahaan dan menjadi pondasi untuk membangun merek yang baik. Merek dapat berupa suatu nama, istilah, simbol, desain atau gabungan keempatnya yang mengidentifikasikan produk para penjual dan membedakannya dari produk pesaing (Lamb, Hair dan McDaniel, 2001:421). Merek merupakan produk atau jasa yang dimensinya dapat membedakan merek tersebut dengan produk atau jasa lain yang dirancang untuk memuaskan kebutuhan yang sama (Kotler dan Keller, 2009:258).

Sehingga, dapat disimpulkan green brand pada dasarnya merupakan identifier yakni sebuah konstruksi yang dipilih oleh pemiliknya berupa logo, nama, simbol, karakter dan lainnya yang dapat melambangkan komitmennya pada lingkungan. Green brand sebagai differentiator dimana suatu merek yang dapat membedakan produk dan jasa lain yang sejenis atas perbedaan dalam berkomitmen terhadap pelestarian lingkungan (Hartman, 2005:10; Lamb, Hair dan McDaniel, 2001:421; Kotler dan Keller, 2009:265).

Prilaku konsumen juga ikut berperan dalam faktor yang mempengaruhi keputusan pembelian, faktor psikologis konsumen seperti persepsi terhadap suatu produk juga berperan dalam pembentukan prilaku konsumen untuk memiliki suatu produk. Brand image dominan muncul dari persepsi yang terbentuk terhadap produk. Persepsi mampu mendorong perasaan emosional dan kecenderungan tindakan yang menguntungkan atau tidak menguntungkan dan bertahan lama dari seseorang terhadap suatu obyek atau gagasan (Kotler, 2012:238). Keterkaitan konsumen pada suatu merek akan semakin kuat jika didasarkan pada cukup banyaknya pengalaman dan persepsi untuk mengkomunikasikannya sehinggaakan terbentuk citra merek (brand image). Citra merek yang terbentuk harapannya mampu menggiring citra merek yang baik, dimana akan mendorong meningkatkan penjualan termasuk citra perusahaan. Citra merek terhadap produk ramah lingkungan dapat dianggap sejenis asosiasi persepsi yang muncul di benak konsumen ketika mengingatsebuah merek produk ramah lingkungan. Asosiasi dapat muncul dalambentuk persepsi, pemikiran atau citra tertentu yang dikaitkan pada merek produk ramah lingkungan, ibaratnya ketika individu atau kelompok berpersepsi atau berpikir mengenai suatu hal.

Sallam (2014) dalam penelitiannya menjelaskan terdapat beberapa indikator dari brand image yang dapat digunakan untuk mengukur brand image dari 
suatu produk, yaitu: 1) Favorability merupakan suatu persepsi perasaan suka konsumen pada brand yang dituju, dimana perasaan inimuncul disebabkan oleh image yang dipancarkan brand tersebut. Apabilasebuah brand mampu memberikan hal yang disukai oleh konsumen, makacitra dari brand tersebut akan semakin baik. 2) Strength merupakan pesepsi konsumen yang muncul ketika melihat suatu brand denganmenyatakan bahwa brand tersebut kuat dan dapat diandalkan. Kuat dalam halini berarti memiliki kekentalan yang menunjukkan salah satu ciri khastertentu. Keandalan merujuk pada sejauh mana seseorang akan memilihsebuah brand karena brand tersebut dapat diandalkan. 3) Uniqueness merupakan perasaan konsumen yang muncul ketika melihat suatu brand dengan menyatakan bahwa brand tersebut memiliki keunikan yang tidak dimiliki produk lain. Pada akhirnya keberadaan brand image diharapkan menjadi salah satu daya tarik konsumen dari suatu produk, sehingga perusahaan haruslah membangun brand image yang positif dimata konsumen. Brand image yang positif ini nantinya akan meningkatkan keinginan atau minat konsumen untuk membeli suatu produk (Zhang, 2015).

Kepribadian merek merupakan sekumpulan karakteristik manusia yang dikaitkan atau dihubungkan dengan merek (Aaker, 1997). Kepribadian merek sebagai campuran sifat manusia tertentu yang dapat di hubungkan dengan merek tertentu. Sama maknanya dengan dua definisi tersebut, Louis dan Lombart (2010) mendefinisikan kepribadian merek sebagai seluruh sifat kepribadian yang digunakan untuk mencirikan seseorang dan memiliki asosiasi dengan merek. Gagasan bahwa benda mati seperti merek dapat dikaitkan dengan seperangkat karakteristik manusia diterima dengan baik oleh para psikolog sosial. Argumen dasarnya adalah bahwa sasaran sikap, seperti merek, dapat dikaitkan dengan ciri-ciri kepribadian yang memberikan manfaat ekspresif atau simbolis diri bagi konsumen. Ekspresi diri dapat menjadi pendorong (driver) yang berpengaruh pada preferensi dan pilihan konsumen (Aaker, 1997).Kepribadian merek terbentuk melalui persepsi konsumen terhadap merek tertentu. Persepsi konsumen tersebut akan tersimpan dalam individu masing-masing (Kapferer, 2008). Dengan kata lain, kepribadian suatu merek berada di benak atau persepsi konsumen yang terbentuk secara langsung maupun tidak langsung melalui pengalaman langsung dalam menggunakan produk atau melalui usaha pemasaran. Kepribadian merek dibentuk melalui nama merek, simbol atau logo, iklan, atribut produk, dan juru bicara (spokesperson) (Grohmann, 2009 ).

Brand Personality merupakan kerangka yang menggambarkan dan mengukur kepribadian merek yang dianalogikan berdasarkan kepribadian manusia, dapat dilihat menjadi lima dimensi (Aaker, 1997). Ketulusan (sincerity). Dimensi ini menunjukkan sifat manusia yang tulus, yang dicerminkan oleh sifat kesederhanaan (down-to-earth), penyayang keluarga (family-oriented), jujur (honest), realistis (realistic), bermanfaat (wholesome), riang (cheerfull), sentimentil serta mudah bergaul (friendly). Ketulusan mencerminkan bagaimana suatu merek benar-benar mampu menunjukkan konsistensi dalam memenuhi kebutuhan, keinginan, dan harapan dari konsumen.

Dimensi lainnya dari brand personality adalah kegembiraan (excitement,) merupakan bagaimana sebuah merek mampu memberikan kegembiraan atau kesenangan pada pemakainya. Hal ini tercermin pada sifat kontemporer (contemporary), mandiri (independent), mutakhir (up-to-date), unik (unique), imajinatif (imaginative), berjiwa muda (young), tenang ( $\mathrm{cool})$, bersemangat (spirited), antusias (exciting), trendi dan berani (daring).

Dimensi ini lebih menunjukkan pada suatu produk atau merek mampu memberikan kesenangan dan kebanggaan. Kecakapan (competence). Dimensi ini ditunjukkan dengan sifat seperti dapat diandalkan (reliable), pekerja keras (hardworking), cerdas (intelligent), memiliki kemampuan teknis (technical), sukses (successful), berjiwa pemimpin (leader) dan percaya diri (confident).

Kecakapan menunjukkan bahwa sebuah merek memiliki kemampuan untuk menunjukkan keberadaannya ataupun eksistensinya di pasar dan kemampuan untuk bersaing. Kecanggihan (sophistication) adalah dimensi yang bisa nampak memiliki sifat seperti golongan atas (upper-class), glamor, berpenampilan menarik (good-looking), mempesona (charming), feminin serta lembut (smooth). Dimensi kecanggihan lebih mengacu kepada bagaimana suatu merek memberikan nilai bagi pemakainya. Ketangguhan (ruggedness) ditunjukkan dengan sifat seperti individu yang menyukai tantangan (outdoorsy), cenderung maskulin, ulet (tough) dan tangguh (rugged). Dimensi ini menunjukkan bagaimana sebuah merek mampu bertahan di tengah persaingan dengan merek lainnya. 


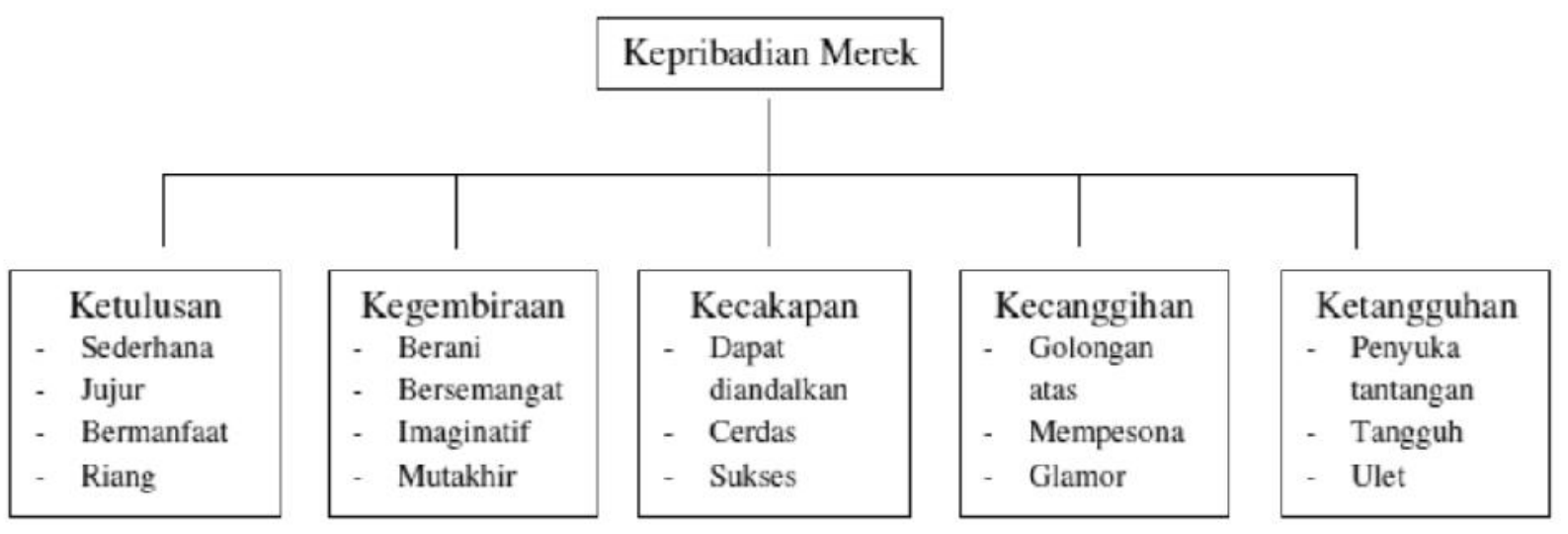

Gambar 1. Model Kepribadian Merek Aaker (1997:352)

Adapun kerangka konsep dalam penelitian ini adalah sebagai berikut.

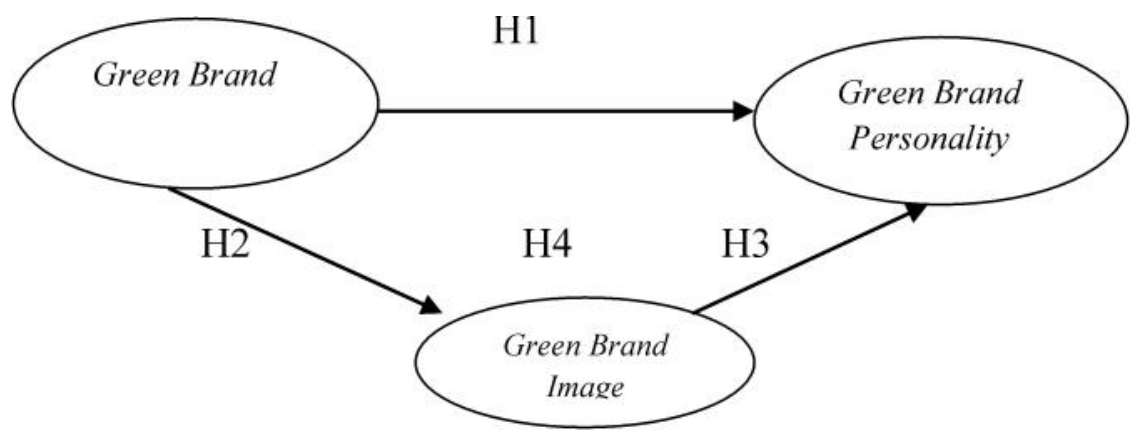

Gambar 2. Kerangka Konsep Penelitian

Sumber: Kajian Penelitian sebelumnya

\section{METODE PENELITIAN}

Penelitian ini menggunakan rancangan penelitian kuantitatif (Creswell, 2010:5). Analisis kuantitatif berdasarkan analisis multivariate menggunakan model persamaan struktural atau SEM (structural equation modeling) berbasis AMOS 7.0. Populasi penelitian ini adalah seluruh masyarakat Bali yang sudah menggunakan produk ramah lingkungan, khususnya adalah produk kesehatan. Pengambilan sampel dengan menggunakan teknik purposive random sampling, dimana tidak semua populasi memiliki kesempatan yang sama sebagai responden dan harus memenuhi kriteria yang dibutuhkan pada penelitian ini. Beberapa kriteria sampel yang dibutuhkan yaitu responden yang berusia minimal 17 tahun, pendidikan minimal SMA dan sederajat, mengetahui keberadaan produk kesehatan berbahan herbal, serta sudah pernah menggunakan produk-produk kesehatan berbahan herbal minimal 3 bulan terakhir.

Penetapan besarnya sampel dilakukan dengan cara mengalikan jumlah indikator dengan 5-10 x jumlah indikator (Malhotra, 2004). Dengan demikian jika jumlah indikator yang diamati berjumlah 11 , maka sampel maksimalnya adalah $11 \times 10=110$ responden yang tersebar di wilayah seluruh Bali.Kuesioner adalah teknik pengumpulan data dengan menggunakan daftar pertanyaan/questioner yang telah dipersiapkan sebelumnya terkait dengan variabel-variabel yang diteliti (Sekaran, 2011:82). Wawancara mendalam dilakukan secara tidak terstruktur, lentur dalam suasana informal, dan dilakukan secara berulang.

Variabel yang diidentifikasi dalam penelitian ini yaitu (1) Variabel eksogen (exogenous variable) adalah green brand $(\mathrm{X})$. Green brand $(\mathrm{X})$ terdiri atas empat indikator pengukuran, yaitu tingkat bahaya merek bagi kesehatan manusia (X1) merupakan penggunaan merek tidak menimbulkan efek samping, kemasan merek (X2) yaitu menggunakan kemasan yang mudah di daur ulang, material bahan baku (X.3) yaitu menggunakan bahan-bahan alami, dan memiliki ecolabel (X4) yaitu merek memiliki label ramah lingkungan. (Rath, 2013). (2) Variabel endogen (endogenous variable) adalah (Y1 dan Y2). Green brand image (Y1) terdiri atas tiga indikator yaitu favorability (Y1.1) merupakan kenyamanan menggunakan merek, strenght (Y1.2) yaitu kemampuan merek memenuhi kebutuhan konsumen dan uniqueness 
(Y1.3) yaitu sesuatu yang berbeda dengan merek lainnya. (Sallam, 2014). Green brand personality (Y2) terdiri atas empat indikator pengukuran yaitu ketulusan (Y2.1) merupakan merek mampu memenuhi harapan konsumen, kegembiraan (Y2.2) yaitu mampu menimbulkan kesenangan terhadap merek, kecakapan (Y2.3) yaitu eksistensidari keberadaan merek dan kecanggihan (Y2.4) yaitu kemampuan merek dalam memberikan nilai kepada konsumen. (Aaker, 1997:348)

Hasil uji validitas dapat membuktikan semua butir pernyataan di dalam instrumen penelitian adalah valid. Validitas terlihat dari hasil korelasi seluruh butir pernyataan pada kuesioner penelitian adalah lebih dari 0,30 .

Tabel 1. Hasil Uji Validitas Instrumen Penelitian Green Brand

\begin{tabular}{llll}
\hline Variabel & Indikator & $\begin{array}{l}\text { Koefisien } \\
\text { Korelasi }\end{array}$ & Ket \\
\hline Green & Tingkat bahaya merek bagi kesehatan manusia & 0,882 & Valid \\
Brand $(\mathrm{X})$ & $\left(\mathrm{X}_{1}\right)$ & 0,849 & Valid \\
& Kemasan merek $\left(\mathrm{X}_{2}\right)$ & 0,871 & Valid \\
& Material bahan baku $\left(\mathrm{X}_{3}\right)$ & 0,878 & Valid \\
& Memiliki ecolabel $\left(\mathrm{X}_{4}\right)$ & & \\
& & 0,906 & Valid \\
Green brand & Favorability $\left(\mathrm{Y}_{1.1}\right)$ & 0,911 & Valid \\
image $\left(\mathrm{Y}_{1}\right)$ & Strenght $\left(\mathrm{Y}_{1.2}\right)$ & 0,913 & Valid \\
& Uniqueness $\left(\mathrm{Y}_{1.3}\right)$ & & \\
Green brand & Ketulusan $\left(\mathrm{Y}_{2.1}\right)$ & 0.868 & Valid \\
personality & Kegembiraan $\left(\mathrm{Y}_{2.2}\right)$ & 0,897 & Valid \\
$\left(\mathrm{Y}_{2}\right)$ & Kecakapan $\left(\mathrm{Y}_{2.3}\right)$ & 0,905 & Valid \\
& Ketangguhan $\left(\mathrm{Y}_{2.4}\right)$ & 0,931 & Valid \\
\hline
\end{tabular}

Sumber: hasil statistik

Reliability adalah ukuran mengenai konsistensi internal dari indikator-indikator sebuah konstruk yang menunjukkan derajat sampai dimana masing-masing indikator mengindikasikan sebuah konstruk yang umum (Ferdinand, 2002:59). Tabel 2 dapat diketahui bahwa semua indikator mampu menjelaskan konstruk yang ada. Hal itu dapat dilihat dari angka construct reliability yang bernilai di atas 0,7, sehingga indikator-indikator tersebut dapat dikatakan reliabel. Hal ini menunjukkan bahwa semua indikator mampu menjelaskan konstruk yang ada. Hal tersebut dapat dilihat dari angka variance extracted $\geq 0,5$.

Tabel 2. Hasil Uji Reliabilitas Konstruk Green Brand

\begin{tabular}{lll}
\hline Konstruk & Variance Extract & Construct Reliability \\
\hline Green brand & 0,55 & 0,83 \\
Green brand image & 0,52 & 0,76 \\
Green brand personality & 0,54 & 0,82 \\
\hline
\end{tabular}

Sumber: hasil statistik

\section{HASIL DAN PEMBAHASAN}

Hasil deskripsi variabel green brand yang disajikan dalam bentuk persentase dan nilai ratarata (mean) pada Tabel 3. Tabel 3 menunjukkan sebaran persepsi responden pada setiap kategori. Rata-rata skor untuk variabel atau konstruk green brand sebesar 4,09. Artinya, responden dalam memenuhi kebutuhan produk makanan kesehatan berbahan herbal akan memperhatikan merek (green brand) dari produk makanan herbal yang akan dikonsumsi.

Indikator yang memiliki respon tertinggi adalah material bahan baku yang digunakan untuk menghasilkan produk dengan merek tersebut dengan rata-rata sebesar 4,22. Artinya bahwa responden dalam keputusan akan memperhatikan green brand dan sangat setuju pentingnya memperhatikan bahan mentah yang digunakan untuk mampu menghasilkan produk kesehatan berbahan alami yang betul-betul berkualitas herbal. Penggunaan material bahan mentah yang digunakan menjadi prioritas konsumen untuk menentukan pilihan merek yang akan dikonsumsi.

Semua hal tersebut akan terkait dengan kepercayaan konsumen pada merek tertentu. Material bahan mentah yang digunakan perlu 
dikomunikasikan dengan baik pada konsumen terkait menjadi variabel yang sangat penting mendukung pilihan merek untuk produk-produk kesehatan ramah lingkungan. Pengkomunikasiaan tersebut dapat dilaksanakan melalui pemanfaatan bauran promosi maupun pada label produk.

Tabel 3. Deskripsi Penilaian Responden Terhadap Indikator Green Brand $(\mathrm{X})$

\begin{tabular}{|c|c|c|c|c|c|c|c|}
\hline \multirow{2}{*}{ Indikator variabel } & \multicolumn{5}{|c|}{$\begin{array}{l}\text { Persentase Respon Responden Dengan } \\
\text { Jawaban }\end{array}$} & \multirow{2}{*}{$\begin{array}{l}\text { Rata- } \\
\text { rata }\end{array}$} & \multirow[b]{2}{*}{ Ket } \\
\hline & 1 & 2 & 3 & 4 & 5 & & \\
\hline $\begin{array}{l}\text { Tingkat bahaya merek bagi } \\
\text { kesehatan manusia }\left(\mathrm{X}_{1}\right)\end{array}$ & 1,8 & 4,5 & 17,3 & 32,7 & 43,6 & 4,12 & $S$ \\
\hline Kemasan merek $\left(\mathrm{X}_{2}\right)$ & 0,9 & 4,5 & 21,8 & 40 & 32,7 & 3,99 & $\mathrm{~S}$ \\
\hline Material bahan baku $\left(\mathrm{X}_{3}\right)$ & 0,9 & 1,8 & 20 & 29,1 & 48,2 & 4,22 & ST \\
\hline Memiliki ecolabel $\left(\mathrm{X}_{4}\right)$ & 0,9 & 6,4 & 22,7 & 27,3 & 27,5 & 4,05 & $\mathrm{~S}$ \\
\hline \multicolumn{6}{|c|}{ Rata-rata variabel Green $\operatorname{Brand}\left(\mathrm{X}_{1}\right)$} & 4.09 & $\mathbf{S}$ \\
\hline
\end{tabular}

Sumber: hasil statistik

Hasil penelitian ini memperkuat hasil penelitian Hartman et al. (2005) bahwa penciptaan merek yang berkomitmen terhadap upaya pelestarian lingkungan yang merupakan bagian dari strategi perusahaan. Strategi tersebut dapat diwujudkan dengan pengunaan material bahan mentah alami yang layak dipercaya konsumen aman dikonsumsi. Temuan ini juga mendukung penelitian Huang dan Yang (2014), dimana salah satu alat komunikasi yang memberikan informasi tentang merek dan manfaat unik produk menyajikan atribut produk ramah lingkungan. Atribut produk tersebut dapat berupa kemasan, material bahan baku serta penggunaan ecolabel untuk lebih meyakinkan konsumen pada merek produk yang memiliki katagori produk ramah lingkungan.
Penilaian responden secara keseluruhan pada penelitian ini, untuk variabel green brand dapat dikatakan bahwa responden setuju jika green brand menjadi perhatian konsumen dalam memutuskan pilihan merek yang dikonsumsi. Terbukti responden perlu memperhatikan tingkat bahaya dari kesalahan memilih merek produk kesehatan herbal, perlu memperhatikan kemasan merek, memperhatikan material bahan baku yang digunakan, termasuk ecolabel yang harus dimiliki oleh merek yang sudah memenuhi standar produk herbal.

Pengukuran green bad imageyang digunakan pada penelitian ini terdiri atas tiga indikator pengukuran, yaitu; favorability (Y1.1), strenght (Y1.2) dan uniqueness (Y1.3). Rekapitulasi tanggapan responden terhadap variabel green brand imagedisajikan pada Tabel 4 .

Tabel 4. Deskripsi Penilaian Responden Terhadap Indikator Green Brand Image $\left(\mathrm{Y}_{1}\right)$

\begin{tabular}{|c|c|c|c|c|c|c|c|}
\hline \multirow{2}{*}{ Indikator variabel } & \multicolumn{5}{|c|}{ Persentase Respon Responden Dengan Jawaban } & \multirow{2}{*}{$\begin{array}{c}\text { Rata- } \\
\text { rata }\end{array}$} & \multirow{2}{*}{ Ket } \\
\hline & 1 & 2 & 3 & 4 & 5 & & \\
\hline Favorability $\left(\mathrm{Y}_{1.1}\right)$ & 0,9 & 4,5 & 15,5 & 31,7 & 42,7 & 4,09 & $\mathrm{~K}$ \\
\hline Strenght $\left(\mathrm{Y}_{1.2}\right)$ & 0,9 & 45 & 20 & 33,6 & 40,9 & 4,09 & $\mathrm{~K}$ \\
\hline Uniqueness $\left(\mathrm{Y}_{1.3}\right)$ & 0,9 & 9,1 & 19,1 & 34,5 & 36,4 & 3,96 & $\mathrm{~K}$ \\
\hline \multicolumn{6}{|c|}{ Rata-rata variabel green brand image $\left(\mathrm{Y}_{1}\right)$} & 4,05 & $\mathbf{K}$ \\
\hline
\end{tabular}

Sumber: hasil statistik

Ketiga indikator pada green brand image memiliki rata-rata yang kuat yaitu sebesar 4,09 untuk variabel favorability, 4,09 untuk strenght dan 3,96 untuk variabel uniqueness. Variabel favorability dan strength memiliki rata-rata tertinggi yang menunjukkan bahwa kesukaan konsumen terhadap merek yang memiliki brand image yang kuat akan menjadi pertimbangan untuk memutuskan pembelian 
terhadap merek tersebut. Hal ini menandakan bahwa green brand image yang kuat akan terbentuk oleh adanya rasa suka di benak konsumen terhadap merek tertentu. Brand image yang kuat harapannya mampu menciptakan brand personality pada produk kesehatan ramah lingkungan. Selain itu, green brand image yang kuat juga didukung oleh adanya persepsi terhadap keandalan dari suatu merek.Hal itu akan menjadi pertimbangan konsumen dalam menentukan pilihan terhadap merek yang memiliki brand image yang kuat. Keandalan merek mampu menciptakan persepsi yang baik terhadap merek di benak konsumen dan mampu menciptakan brand personality yang baik. Temuan ini hkususnya pada pemenuhan kebutuhan kesehatan berbahan herbal dengan merek ramah lingkungan mampu mendukung temuan Zhang (2015).

Green brand personality pada penelitian ini diukur dengan menggunakan empat indikator pengukuran yaitu ketulusan (Y2.1), kegembiraan (Y2.2), kecakapan (Y2.3) dan kecanggihan (Y2.4).Rekapitulasi tanggapan responden terhadap variabel green brand personalitydisajikan pada Tabel 5 .

Tabel 5. Deskripsi Penilaian Responden Terhadap Indikator Green Brand Personality (Y2)

\begin{tabular}{|c|c|c|c|c|c|c|c|}
\hline \multirow{2}{*}{ Indikator variabel } & \multicolumn{5}{|c|}{ Persentase Jawaban Responden (\%) } & \multirow{2}{*}{$\begin{array}{l}\text { Rata- } \\
\text { rata }\end{array}$} & \multirow{2}{*}{ Ket } \\
\hline & 1 & 2 & 3 & 4 & 5 & & \\
\hline Ketulusan (Y2.1) & 0,9 & 5,5 & 20 & 28,2 & 45,5 & 4,12 & $\mathrm{~S}$ \\
\hline Kegembiraan (Y2.2) & - & 5,5 & 25,5 & 29,1 & 40 & 4,04 & S \\
\hline Kecakapan (Y2.3) & - & 4,5 & 28,2 & 27,3 & 40 & 4,03 & $\mathrm{~S}$ \\
\hline Ketangguhan (Y2.4) & 1,8 & 8,2 & 29,1 & 23,6 & 37,3 & 3,86 & $\mathrm{~S}$ \\
\hline
\end{tabular}

Sumber: hasil statistik

Tabel 5 menunjukkan bahwa nilai rata-rata untuk variabel green brand personalityadalah sebesar 4,01. Artinya, responden setuju bahwa green brand personality adalah merupakan variabel penting yang mendukung eksistensi dari suatu produk. Produk yang kuat sangat didukung oleh brand personality yang terbentuk di benak konsumen. GreenBrand personality yang baik menjadi dasar dalam pemilihan merek dalam keputusan pembelian konsumen.

Indikator yang berada di atas rata-rata skor yaitu indikator ketulusan sebesar 4,12, indikator kegembiraan dengan rata-rata nilai sebesar 4,04, dan indikator kecakapan sebesar 4,03. Berarti bahwa green brand personality yang baik menurut persepsi responden akan sangat kuat dibentuk oleh kemampuan merek dalam memenuhi kebutuhan dan keinginan konsumen, kemampuan merek dalam memberikan manfaat yang dirasakan dengan menggunakan merek, kemampuan merek dalam memberikan kepuasan yang diharapkan konsumen. Berarti bahwa kepribadian merek (green brand personality)produk kesehatan yang ramah lingkungan terbentuk melalui persepsi konsumen terhadap merek tersebut. Persepsi konsumen tersebut akan tersimpan dalam individu masingmasing. Hal ini sangat mendukung temuan penelitian Kapferer (2008).

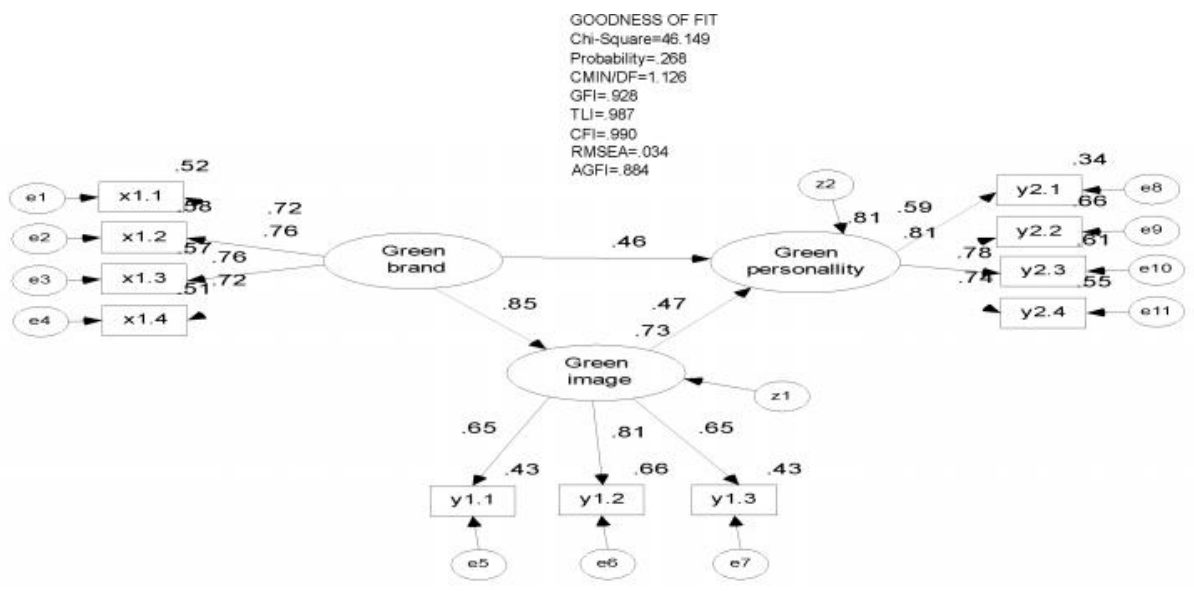

Gambar 3. Model Green Brand Personality Bagi Merek Ramah Lingkungan(Green Brand) 
Masing-masing indikator dapat diterima dan digunakan untuk mendefinisikan variabel laten (konstruk) berdasarkan hasil estimasi model pengukuran yang dilakukan dengan teknik comfirmatory factor analysis, maka estimasi dilanjutkan pada estimasi model persamaan struktural dengan teknik full model analysis.
Estimasi ini ditujukan untuk melihat kesesuaian model dan hubungan kausalitas yang terjadi pada suatu hubungan yang berjenjang.

Hasil uji kesesuaian (goodness of fit) model pengaruh komitmen lingkungan terhadap sukses produk baru yang dimediasi oleh inovasi hijau disajikan dalam Tabel 6.

Tabel 6. Goodness of Fit Indexes Model

\begin{tabular}{ccrc}
\hline Goodness of Fit Index & Cut of Value & Hasil Model & Keterangan \\
\hline Probability $(P)$ & $\geq 0,05$ & 0,268 & Baik \\
$X^{2}$-Chi-Square & $<79,08$ & 46,149 & Baik \\
& $(\mathrm{df}=60, \alpha=0,05)$ & & \\
CMIN/DF & $\leq 2,00$ & 1,126 & Baik \\
GFI & $\geq 0,90$ & 0,928 & Baik \\
TLI & $\geq 0,95$ & 0,987 & Baik \\
CFI & $\geq 0,95$ & 0,990 & Baik \\
RMSEA & $\leq 0,08$ & 0,034 & Baik \\
AGFI & $\geq 0,90$ & 0,884 & Marginal \\
\hline
\end{tabular}

Sumber: hasil statistik

Tabel 6 menunjukkan bahwa semua kriteria indeks goodness offit bernilai baik dan ditunjukkan dengan nilai $X^{2}$ (Chi-Square) sebesar 46,149 dan probability lebih dari 0,05 yaitu 0,268 , Indeks $G F I$ dengan nilai 0,928 sudah baik dan indeks $A G F I$ dengan nilai 0,884 berada dalam kriteria marginal. Selanjutnya indeks $C M I N / D F$ dengan nilai 1,126 , TLI dengan nilai 0,987, CFI dengan nilai 0,990 dan RMSEA dengan nilai 0,034 , semuanya berada dalam kreteria baik. Indeks $T L I$ dan $C F I$ sangat dianjurkan digunakan, karena indeks ini relatif tidak sensitif terhadap besarnya sampel dan kurang dipengaruhi oleh kerumitan model (Ferdinand, 2002 : 76), sehingga model ini sudah memenuhi standar goodness of fit dilihat dari nilai TLI (Tucker Lewis Index) dan CFI (Comperatif Fit Index).
Berdasarkan hasil estimasi standardizedregressions weights pada Tabel 7 dapat diketahui bahwa koefisien jalur pengaruh green brand $(\mathrm{X})$ terhadap green brand personality $\left(\mathrm{Y}_{2}\right)$ adalah sebesar 0,460 dengan tingkat signifikansi sebesar 0,040. Hal ini menunjukkan bahwa ada pengaruh yang signifikan antara green brand terhadap green brand personality. Variabel green brand $\left(\mathrm{X}_{1}\right)$ juga berpengaruh signifikan terhadap green brand image $\left(\mathrm{Y}_{1}\right)$ dengan koefisien jalur sebesar 0,855 dengan tingkat signifikansi sebesasr 0,000 . Variabel green brand image $\left(\mathrm{Y}_{1}\right)$ berpengaruh signifikan terhadap greenbrand personality $\left(\mathrm{Y}_{2}\right)$ dengan koefisien jalur sebesar 0,472 dengan nilai signifikansi sebesar 0,044 .

Tabel 7. Estimasi Regression Weights Model Green Brand Personality Bagi Merek Ramah Lingkungan (Green Brand)

\begin{tabular}{|c|c|c|c|c|c|c|c|}
\hline & & & $\begin{array}{l}\text { Estimate } \\
\text { Unstandar } \\
\text { - dize }\end{array}$ & E. & $\begin{array}{l}\text { Estimate } \\
\text { Standar- } \\
\text { dize }\end{array}$ & C.R. & $\mathrm{P}$ \\
\hline $\begin{array}{l}\text { Green } \\
\text { Personality }\end{array}$ & $<--$ & Green Brand. & .512 & .249 & .460 & 2.054 & 0.04 \\
\hline $\begin{array}{l}\text { Green Brand } \\
\text { Image }\end{array}$ & $<--$ & Green Brand & .783 & .145 & .855 & 5.405 & 0.00 \\
\hline $\begin{array}{l}\text { Green Brand } \\
\text { Personality }\end{array}$ & $<--$ & $\begin{array}{l}\text { Green Brand } \\
\text { Image }\end{array}$ & .572 & .284 & .472 & 2.017 & 0.04 \\
\hline
\end{tabular}

Sumber: hasil statistik

Analisis pengaruh langsung, pengaruh tidak langsung dan pengaruh total dari variabel yang diteliti ditujukan untuk mengetahui kekuatan pengaruh antar konstruk, baik pengaruh langsung, tidak langsung maupun pengaruh total. Hasil analisis program AMOS terhadap pengaruh langsung, pengaruh tidak langsung dan pengaruh total dari masing-masing variabel yang diteliti adalah seperti dalam Tabel 8. 
Tabel 8. Pengaruh Langsung, Pengaruh Tidak Langsung dan Pengaruh Total Model Green Brand Personality Bagi Merek Ramah Lingkungan (Green Brand)

\begin{tabular}{llc}
\hline \multicolumn{1}{c}{ Tipe Pengaruh } & \multicolumn{1}{c}{ Konstruk } & $\begin{array}{c}\text { Standardized } \\
\text { Estimates }\end{array}$ \\
\hline Pengaruh & Green Brand -> Green Brand Personality & 0,460 \\
Langsung & Green Brand -> Green Brand Image & 0,855 \\
& Green Brand Image-> Green Brand Personality & 0,472 \\
Pengaruh & Green Brand -. Green Brand Personality & \\
Tak Langsung & Green Brand -. Green Brand Personality & 0,405 \\
Pengaruh Total & & 0,864 \\
& & \\
\hline
\end{tabular}

Sumber: hasil statistik

\section{Pengaruh Green Brand Terhadap Green Brand Personality}

Pengujian terhadap hipotesis 1 penelitian ini menghasilkan nilai koefisien jalur (standardized direct effect) sebesar 0,460. Selanjutnya nilai Pvalue yang diperoleh pada hubungan variabel green brand $(\mathrm{X})$ terhadap green brand personality $\left(\mathrm{Y}_{2}\right)$ adalah 0,040 . Hal ini dapat diartikan bahwa green brand berpengaruh positif dan signifikan terhadap green brand personality. Semakin baik persepsi konsumen terhadap merek-merek yang dimiliki oleh produk ramah lingkungan khususnya merek produk kesehatan, maka semakin baik pula persepsi konsumen terhadap green brand personality dari produk tersebut.

Temuan penelitian ini memperkuatpenelitian Waskito dan Harsono (2011), yang mengungkapkan bahwa sebagai salah satu bentuk keunggulan dari suatu merek dapat dilakukan dengan menciptakan green brand bagi produk ramah lingkungan. Persepsi green brand yang baik pada konsumen dapat lebih menjamin stabilitas keutusan pembelian dengan meningkatnya kesadaran masyarakat terhadap kelestarian lingkungan. Berarti juga bahwa didalammya akan mampu menciptakan green brand personality yang baik pula. Terbentuknya green brand personality yang baik akan sangat membantu penerapan strategi produk ramah lingkungan dan mampu membantu mendorong tumbuhnya bisnis hijau di masyarakat.

Temuan ini juga mendukung pendapat Hartmann (2005), menyatakan bahwa strategi produk ramah lingkungan yang diterapkan perusahaan mampu membentuk persepsi tertentu terhadap green brand. Green brand yang terbentuk mampu mengarahkan pada keputusan pembelian produk ramah lingkungan, karena kesadaran konsumen dalam menjaga lingkungan alam. Kesadaran tersebut tanpa disadari secara implisit disebabkan karena persepsi yang baik terhadap gren brand personality dari suatu produk ramah lingkungan.

\section{Pengaruh Green Brand Terhadap Green Brand Image}

Nilai koefisien jalur (standardized direct effect) yang diperoleh dari pengaruh komitmen lingkungan terhadap sukses produk baru sebesar 0,855 . Selanjutnya nilai P-value yang diperoleh pada hubungan variabel green brand $(\mathrm{X})$ terhadap green brand image $\left(\mathrm{Y}_{1}\right)$ adalah 0,000 . Hal ini dapat diartikan bahwa green brand berpengaruh positif dan signifikan terhadap green brand image. Semakin baik persepsi konsumen terhadap merek dari produk hijau khususnya produk makanan kesehatan maka semakin kuat green brand image yang terbentuk. Green brand image yang dimaksud disini adalah dilakukan dengan pengukuran tiga indikator yaitu favorability, strengthdan uniqueness. Temuan penelitian ini sangat sesuai dengan yang diungkapkan Paulray (2008). Menyebutkan bahwakarakteristik yang terdapat pada sebuah produk hijau harus dapat menjadi nilai utama yang bisa ditawarkan kepada konsumen. Sebab manfaat dan nilai yang ditawarkan dapat memberikan citra secara pribadi pada konsumen.

Sehingga nilai utama dari green product akan mampu menciptakan green brand image yang baik pula. Namun temuan penelitian ini akan bertolak belakang dengan temuan Alshura dan Zabadi (2016) yang menyatakan bahwa green brand imagetidak berpengaruh pada pilihan merek konsumen.

\section{Pengaruh Green Brand Image Terhadap Green Brand Personality}

Koefisien jalur (standardized direct effect) yang diperoleh dari pengaruh inovasi hijau terhadap sukses produk baru adalah sebesar 0,472. Dimana 
nilai P-value yang diperoleh pada hubungan variabel green brand image $\left(\mathrm{Y}_{1}\right)$ terhadap green brand personality $\left(\mathrm{Y}_{2}\right)$ adalah 0,040 . Hal ini dapat diartikan bahwa green brand imageberpengaruh positif dan signifikan terhadap green brand personality. Semakin kuat persepsi konsumen terhadap image dari merek produk hijau khususnya merek produk kesehatan maka semakin baik pula persepsi green brand personalityyang terbentuk pada merek tersebut. Temuan ini khususnya pada pemenuhan kebutuhan kesehatan berbahan herbal dengan merek ramah lingkungan mampu mendukung temuan Zhang (2015). Bahwa, keberadaan brand image yang yang kuat diharapkan menjadi salah satu daya tarik konsumen dari suatu produk, sehingga perusahaan haruslah membangun brand image yang kuat dimata konsumen. Brand image yang kuat ini nantinya akan menciptakan brand personality dan meningkatkan keinginan atau minat konsumen untuk membeli suatu produk.

\section{Peran Green Brand Image Memediasi Hubungan Antara Green Brand Terhadap Green Brand Personality}

Pengaruh langsung green brandterhadap green brand personality sebesar 0,460 lebih dari pengaruh tidak langsung hubungan antara green brandterhadap green brand personality yaitu sebesar 0,403. Hal ini berarti green brand berpengaruh langsung terhadap green brand personality dengan tanpa melalui green brand image. Semakin baik persepsi green brand konsumen maka semakin baik persepsi green brand personality yang terbentuk. Dimana, keadaan ini menandakan green brand personalitytidak dipengaruhi oleh kuatnya green brand image. Sehingga, tanpa adanya kekuatan gren brand imagemaka green brand juga mampu menciptakangreen brand personality yang baik. Hasil penelitian ini sesuai dengan temuan Alshura dan Zabadi (2016) yang menyatakan bahwa green brand image tidak berpengaruh pada pilihan merek konsumen. Khusus pada penelitian ini green brand image juga bukan sebagai variabel mediasi hubungan antara green product terhadap green brand personality.

\section{SIMPULAN DAN SARAN}

Hasil penelitian menghasilkan beberapa kesimpulan sebagai berikut: a) Green brand berpengaruh positif dan signifikan terhadap green brand personality. Berarti bahwa semakin baik persepsi konsumen terhadap green brand yang dimiliki, maka akan semakin baik pula persepsi terhadap kepribadian merek (green brand personality) yang terbentuk. b) Green brand berpengaruh positif dan signifikan terhadap green brand image. Semakin baik persepsi konsumen terhadap merek hijau produk kesehatan (green brand), maka akan semakin semakin kuat green brand personality merek tersebut dimata konsumennya. c) Green brand image berpengaruh positif dan signifikan terhadap green brand personality. Semakin kuat green brand image di benak konsumen maka akan semakin baik green brand personality yang dimiliki merek yang bersangkutan. d) Pengaruh langsung green brand image terhadap green brand personality memiliki nilai lebih besar dibandingkan dengan pengaruh tidak langsung. Tanpa adanya green brand image menunjukkan bahwa green brand mampu berpengaruh terhadap green brand personality.

Bagi produsen merek kesehatan ramah lingkungan perlu memperhatikan terkait kemasan mereknya agar benar-benar mampu mencirikan merek dari produk ramah lingkungan, misalnya dengan menggunakan simbol yang berhubungan dengan lingkungan alam maupun warna hijau. Perlu juga untuk memperhatikan keunikan dari merek yang ditawarkan dibandingkan dengan merek-merek lainnya, misalnya mampu memberikan manfaat unik maupun tampilan yang unik. Serta, perlu meningkatkan kemampuan ataupun manfaat yang diberikan dari merek tersebut, seperti merek mampu memberikan beberapa manfaat pada konsumennya.

\section{Keterbatasan Penelitian}

Penelitian ini masih secara umum pada seluruh merek ramah lingkungan untuk kebutuhan kesehatan. Belum merujuk secara spesifik merek kesehatan tertentu, sehingga selanjutnya penting untuk melakukan penelitian lebih spesifik misalnya pada makanan suplemen, atau minuman untuk kesehatan, atau obat-obatan alami berbahan herbal lainnya.

\section{REFFERENCE}

Aaker, J.L. 1997, Dimensions of brand personality. Journal of Marketing Research, 34, pp. 347-56.

Alshura, M.S \& Zabadi, A.M. 2016. Impact of green brand trust, green brand awareness, green brand image, and green perceived value on consumer's intension to use green products: an empirical study of jordanian consumers. International Journal of Advanced Research, 4(2), pp.1423-1433 
Albino V; Azzurra B \& Rosa M. D. 2009. Environmental strategies and green product development: an overview on sustainabilitydriven companies. Business Strategy and the Environment Bus. 18, 83-96

Chen, Y-S., \& Chang, C-H. 2016. Green brand personality and green purchase intentions: the mediation roles of green brand associations and green brand attitude. International Journal of Management and Applied Science. 2(2), pp. $114-118$

Creswell, J W. 2010. Research Design: Pendekatan Kualitatif, Kuantitatif dan Mixed. Cetakan 1. Yogyakarta: Pustaka Pelajar.

D’Souza, C.; Taghian, M.; Lamb, P.; \& Peretiatkos, R. 2006. Green products and corporate strategy: An empirical investigation. Society and Business Review, 1(2), pp.144-157.

Delgado-B, E. \& Munuera-A, J.L. 2005. Does brand trust matter to brand equity?, Journal of Product and Brand. Management, 14, pp. 187-96.

Ekawati, NW., Rahyuda, I.K., Kerti Yasa N.N dan Sukaatmadja, I.P.G. 2016. The Implementation of Ecopreneurship and Green Innovation in Building Competitive Advantage to Generate Success of New Spa Product in Bali. International Business Management. 10(14), pp. 2660-2669.

Ekawati, N.W; Kerti Yasa, N.N; Giantari, dan I.G.A., Sariyathi, N.K. 2017. Ecopreneurship and Green Innovation for the Success of New Spa Products. Journal of Business and Retail Management Research (JBRMR), 11 Issue 3, pp. 13-24.

Elkington, J. 1997. Cannibals with Forks: The triple bottom line of 21st century business. BC, Canada: New Society Publishers.

Ferdinand A. 2006. Metode Penelitian Manajemen. Semarang: BPUNDIP

Grohmann, B. 2009. Gender Dimensions of Brand Personality. Journal of Marketing Research, 46(1), pp. 105-19.

Hartman P; Vanesa I; \& Javier F. S. 2005. Green Branding Effects on Attitude: Functional versus Emotional Positioning Strategies. Marketing Intelligence \& Planning, 23(1), pp. 9-29.

Hee, P. S. 2009. The antecedents and consequences of brand image: Based on Keller's customerbased brand equity. The Ohio State University, ProQuest, UMI Dissertations Publishing.
Huang Y-C \& Yang M. 2014. Effects of green brand on green purchase intention. Marketing Intelligence \& Planning 32(3), pp. 250-268

Ismail, A.R. \& Spinelli, G. 2012. Effects of brand love, personality and image on word of mouth: The case of fashion brands among young consumers. Management, 16(4).

Kapferer, J.N. 2008 The new strategic brand management; Creating and sustaining brand equity long term, Fourth edition, Kogan page Limited, London and Philadelphia.

Kotler, P. 2012. Manajamen Pemasaran, Jilid 2. Jakarta: PT Indeks Kelompok Gramedia.

Kotler, P. \& Lee, N. 2005. Corporate social responsibility: Doing the most good for your company and your cause. New Jersey: John Wiley \& Son, Inc

Lee, H.J. \& Kang, M.S. 2012, The effect of brand experience on brand relationship quality, Academy of Marketing Studies Journal, 16(1), pp. 87- 98.

Louis, D. \& Lombart, C. 2010. Impact of brand personality on three major relational consequences (trust, attachment, and commitment to the brand). Journal of Product \& Brand Management. 19(2), pp. 114-130.

Ottman, J, 1998. Developing Green Products: Learning From Stakeholder. Asia Pacific Journal or Marketing and Logistics, 10(1), pp. 22-43.

Paulray, A. 2008. Environmental motivations: a classification scheme and its impact on environmental strategies and practices. Journal of Business Strategy and the Environment, 18(7), pp. 453-468.

Sallam, Methaq, Ahmad.2014. The Effect of Brand Identification on Brand Love and Purchase Decision Making: The Role of WOM. International Business Research; 7(10), pp.187-193.

Schaltegger, S. 2002. A Framework and typology of ecopreneurship: Leading bioneers and environmental mangers to ecopreneurship. Making Ecopreneurs: Developing Sustainable Entrepreneurship. $2^{\text {nd }}$ Edition. USA: Ashgate publishing group. pp. 45-58.

Sekaran, Uma. 2011.Research Method fo Business, Metode Penelitian untuk Bisnis. Jakarta: Salemba Empat.

Shobeiri, A.M., Omidvar, B. \& Prahallada, N.N. 2006, 'Influence of gender and type of school on environmental attitude of teachers in Iran 
166 Matrik: Jurnal Manajemen, Strategi Bisnis dan Kewirausahaan Vol. 12, No. 2, Agustus 2018

and India', International Journal of Science and Technology, 3(4), pp. 351-7.

Sirgy, M.J. 1982, Self-concept in consumer behavior: a critical review, Journal of Consumer Research, 17, pp. 412-25.

Rath, Ramesh Chandra. 2013. An Impact of Green marketing on Practices of Supply Chain Management in Asia: Emerging Economic Opportunities and Challenges. International Journal of Supply Chain Management, 1(2), pp. $78-86$.
Warta Ekspor. 2014. Kementrian Perdagangan Republik Indonesia, Edisi September.

Waskito, Jati \& Mugi Harsono. 2012. Green Consumer: Deskripsi Tingkat Kesadaran dan Kepedulian Masyarakat Joglosemar terhadap Kelestarian Lingkungan. Jurnal Dinamika Manajemen, 3(1): 29-39.

Zhang Yi. 2015. The Impact of Brand Image on Consumer Behavior: A Literature Review. Journal of Business and Management. 3, pp. $58-62$. 